Article

\title{
Impact of Participation in Contract Farming on Smallholder Farmers' Income and Food Security in Rural Benin: PSM and LATE Parameter Combined
}

\author{
Odountan Ambaliou Olounlade ${ }^{1}$, Gu-Cheng Li ${ }^{1, *}$, Sènakpon E. Haroll Kokoye ${ }^{2}$, \\ François Vihôdé Dossouhoui ${ }^{3}$, Kuassi Auxence Aristide Akpa ${ }^{4}$, Dessalegn Anshiso ${ }^{1} \mathbb{1}$ and \\ Gauthier Biaou 5 \\ 1 College of Economics and Management, Huazhong Agricultural University, No. 1 Shizishan Street, \\ Hongshan District, Wuhan 430070, China; a.olounlade@webmail.hzau.edu.cn (O.A.O.); \\ anshiso39@gmail.com (D.A.) \\ 2 Department of Agricultural Economics and Rural Sociology, Auburn University, Auburn, \\ Alabama, AL 36849, USA; sek0013@auburn.edu \\ 3 Department of Economy Socio-Anthropology and Communication, University of Abomey-Calavi, \\ Cotonou 01BP526, Benin; dossouhoui@yahoo.fr \\ 4 Faculté de Philosophie, Arts et Lettres, Université Catholique de Louvain, 1348 Louvain-la-Neuve, Belgium; \\ aristide.akpa@student.uclouvain.be \\ 5 School of Agribusiness and Agricultural Policy, National University of Agriculture of Benin, \\ Porto-Novo 01BP55, Benin; gbiaou@yahoo.fr \\ * Correspondence: lgcabc@mail.hzau.edu.cn; Tel.: +86-02787286896
}

Received: 16 December 2019; Accepted: 13 January 2020; Published: 26 January 2020

\begin{abstract}
Investigated in this work is the impact of contract farming participation on smallholder farmers' income and food security in rice crop production in Northern Benin using 400 randomly selected rice farmer households. Unlike previous studies, we corrected for both observed and unobserved biases by combining propensity score matching (PSM) and the local average treatment effect parameter (LATE). The results showed significant negative consequences of partaking in rice contract farming. We found evidence of significant negative effects on rice production income at a $1 \%$ level. The more the rice farmers join in contract farming, the lower the farm income became. Decreased food consumption was also a result of contract farming participation for potential participants by a score of 60.64, placing their households at the food security status level of poor food consumption because the quantity and nutritional quality of the food consumed were inadequate. Contract farming is, therefore, not a reasonable policy instrument that can help farmers increase their income and improve their food security level in the Alibori Department, Benin if farmers do not diversify their crops. The necessary resources and economic environment are not yet in place to allow contract farming to take full advantage of its potential benefits. To prevent the wasting of scarce public resources, expanding contract farming would not be appropriate in marginal areas with markets and other infrastructure. Additional measures are needed for contract farming to be profitable for contracting actors and to ensure sustainability and the large-scale participation of farmers.
\end{abstract}

Keywords: contract farming; impact; income; food security; rice; Benin

\section{Introduction}

Despite the benefits of economic specialization being comprehended quite ever since The Wealth of Nations [1] was published by Adam Smith, when noting advance, some chronic loss of specialized work can be among the causes of underdeveloped economic potential in the poorest nations of the 
globe. Such as those nations, the economies of which continue to be mainly agrarian, the structural transformation migrating to agriculture based on commerce from agriculture for subsistence has been difficult. Most smallholder farmers value self-sufficiency in production. In other words, these farmers grow for their own consumption purpose due to production restrictions [2].

Among African nations, mainly in Benin, the agricultural zone is characterized by many smallholder farmers who face considerable market constraints, including negative marketplace records, constrained access to credit, cutting-edge inputs, and high transaction expenses due to weak market integration [3]. Even though demand for staple foods is high, farmers are still afraid to commit to unproductive production. This has been observed in rice production, as this agricultural product is daily consumed in both urban and rural areas [4], resulting in high demand. Approximately $47 \%$ of this need is satisfied by domestic farming production; the balance is imported. [5] Contract farming (CF) is viewed by smallholder rice farmers as a possible answer to overcome these restrictions for farmers with poor resources. With contract farming, farm production is sold in advance with the aid of a company in trade for certain offerings, including prefinancing of inputs. Despite CF being basically a commercial initiative, settlement farming can be considered a means of improvement to assist smallholder farmers in overcoming the demanding situations they face while trying to gain entry to larger remunerative markets. CF enables farmers to connect to output markets and often provides inputs, credit scores, or agricultural extensions. With contract farming, farm production is sold in advance with the aid of a company in trade for certain offerings, including prefinancing of inputs. Despite CF being basically a commercial initiative, settlement farming can be considered a means of improvement to assist smallholder farmers in overcoming the demanding situations they face while trying to gain entry to larger remunerative markets. CF enables farmers to connect to output markets and often provides inputs, credit scores, or agricultural extensions [6-8]. Contract farming has been claimed to positively impact local economies by improving the welfare of rural households. Several authors have found that farmers' incomes are increased by participation in contract farming [3]. Nevertheless, efforts to improve the effect of contract farming on farmers' agricultural earnings and food security need understanding and recognition of the constraints and opportunities of farmers' involvement in contract farming.

Empirical evidence is limited on the impact of agricultural systems such as contract farming in Africa. Several studies on such impacts [9-13] have shown that the characteristics of contracting and noncontracting farmers have similar effects on outcome variables. Every one of these investigations have focused on crops, for example, rice, cotton, maize, poultry, and vegetables [14-17].

Most studies [11,18-21] used a single econometric model to determine the result of the participation in contract farming, the hardiness of their efforts and that the farmers using contracts do not represent a cross-section of the people, and that differences within the population can have a negative or positive impact on farmers profits. For example, there may be a variance in observable traits, including such valuable skills as intellect and productivity, the size of the farm, and the education of the farmer. Regardless, the differences in profits between the contract and noncontract farmers is a reflection of both the different traits and the participation in contracts [22].

The attempt in this study is to speak to this evidence gap using a micro viewpoint on partaking in contract farming and its effects on the agricultural income and food security farmers. The methods of the propensity score matching (PSM) and the local average treatment effect (LATE) were combined. The significance for income and food security small rice farmers in Alibori Department, particularly in the Malanville, Banikoara, Kandi, and Karimama municipalities in Benin of participating in contract farming was assessed. The issue is appropriate for consideration of food strategy choices in that if contract farming has a beneficial impact on the small rice farmers, then programs and agendas backing contract farming can be deemed necessary on the basis of equality. If the impact is negative, then those charged with creating policies should decide that different agricultural improvement strategies should be supported. The significance of this research is in the implications for discussing whether small 
farmers are able to adjust to globalization, which will accelerate the need for innumerable vertical economic activities, including contract farming.

The balance of the study is structured in the following manner: The data collection method applied in four districts in Northern Benin, as well as the conceptual framework and estimation technique are introduced in Section 2. Section 3 presents and discusses the empirical results. Section 4 provides the conclusions and implications of the findings.

\section{Materials and Methods}

\subsection{Study Areas}

The study was conducted in the department of Alibori (similar to the states in USA). Alibori has an area of 2.62 million ha, of which $80 \%$ is cultivated. The main criteria for selecting Alibori Department as the study area were: (1) It is the premier rice-producing region in Benin and where contract farming is practiced, and (2) it ranks third in the country regarding potential in the lowlands (33,000 ha) after the Zou-Collines and Atacora-Donga Departments [4].

The year 1999 saw the creation of the Department of Alibori. This administrative division was formerly a part of the Borgou Department. The capital of the departments has been Kandi, since 2008. There are six subdivisions in the Alibori Department, each is positioned around one of the principal towns: Banikoara, Malanville, Gougounou, Kandi, Karimama, and Ségbana. We focused on farmers' participation in contract farming as a management strategy to manage the challenges of rice production in four rice-producing districts (Banikoara, Kandi, Karimama and Malanville) in Alibori. These districts were randomly selected on the basis of their offers in all-out rice production in the department. The statistical data from these districts on their socioeconomic characteristics and exposure to different forms of production difficulties despite the existence of contract farming in the department were also taken into account in the selection. The location of the selected study area is depicted in Figure 1.

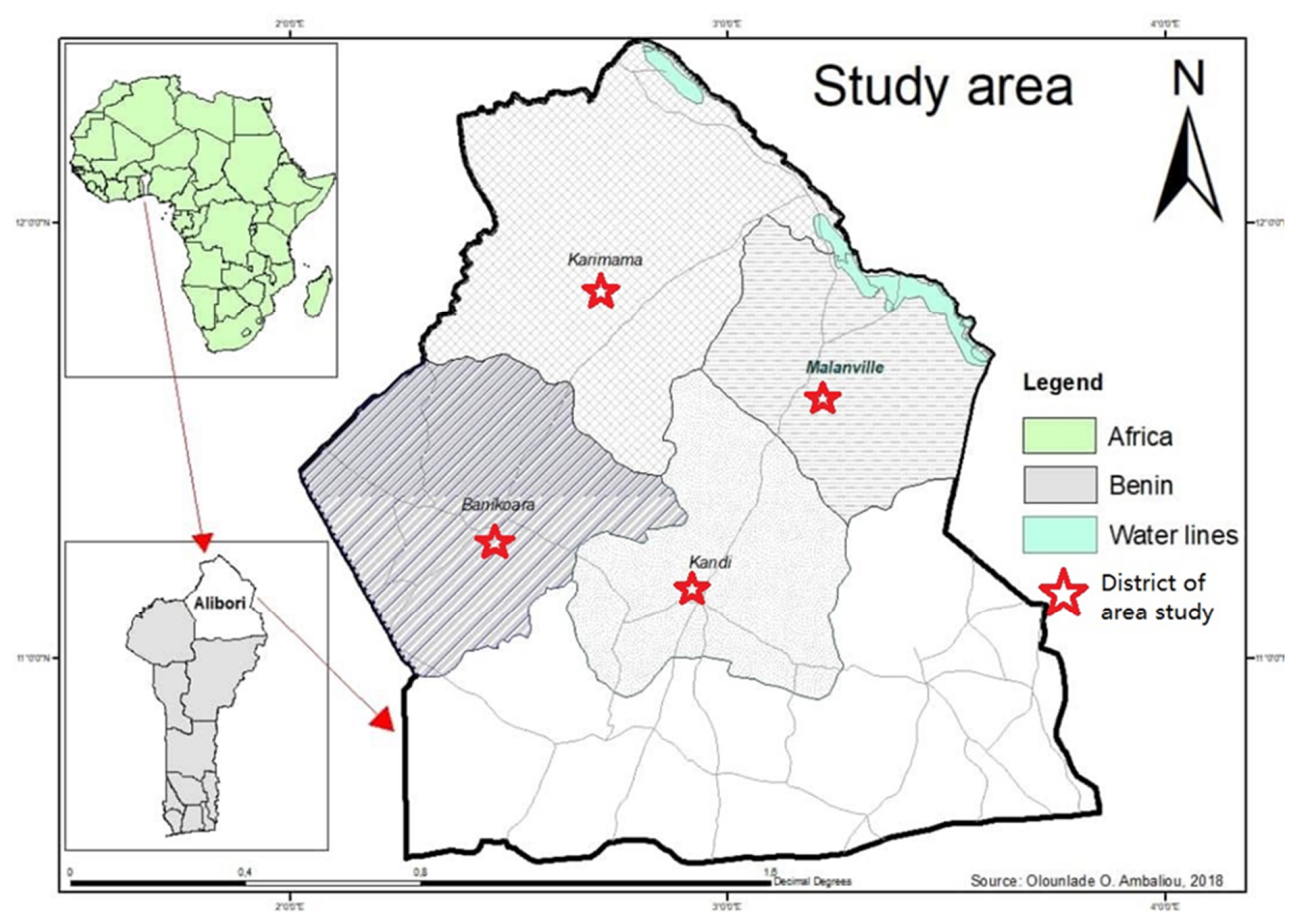

Figure 1. Study area. 


\subsection{Data Collection and Sampling Methods}

On the way to achieve the research objective, we used a multistage random selection method to choose the investigation territory and homestead family units. In the initial phase, Alibori Department was chosen as the fundamental examination zone dependent on its higher commitment toward all out agricultural gross domestic products in Benin. In the subsequent advance, we randomly chose four districts where rice is produced. In the third and fourth steps, from each selected district, two subdistricts and five villages per subdistrict were chosen using random selection methods. During the last phase, ranch family units were chosen from every village from the list of farmers provided by the Territorial Agency for Agricultural Development. Figure 2 outlines the sampling framework.

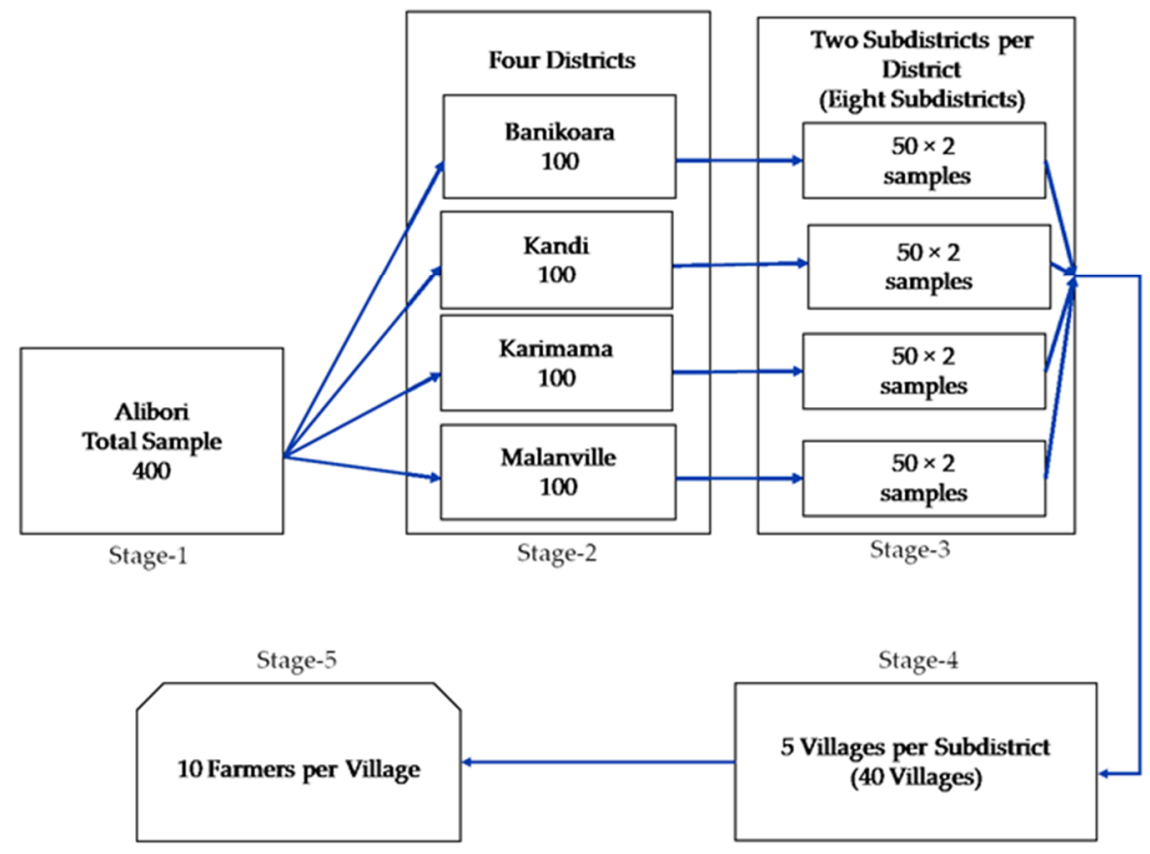

Figure 2. Proposed sampling framework.

Specifically, data collection was automated using a smartphone Android Huawei P9 (Huawei, Shenzhen, China) with a computer-aided personal interview (CAPI) software, such as Kobocollect developed by the Harvard Humanitarian Initiative based in Cambridge, MA, USA. Many biases were avoided by the computer-based data collection instead of paper questionnaires, which in the past often resulted in bad data including such instances as changes in the values of the variables and incorrect recording of numerical variables of test answers. One hundred respondents from each district were selected and interviewed between January 2019 and April 2019. Yamane's [23] formula was employed in the selection of the farm household sample for the area studied, i.e.,:

$$
n=\frac{N}{1+N e^{2}}
$$

where $n$ is the size of the sample for a village, $N$ is the farming household total number in a village, and $e$ is the precision, which was set at $\pm 15 \%(0.15)$.

The plan of the interview incorporated all the important data concerning contract farming knowledge and participation, constraints to market participation, socioeconomic profiles, input markets, access to services and markets for rice and other farm outputs, and indicators to assign a score to farmers' food security. Prior to starting the survey, pretesting was carried out to prevent the loss of any essential information. The distribution of respondents by district is shown in Table 1. 
Table 1. Distribution of respondents by district.

\begin{tabular}{cccc}
\hline District & Contract & Noncontract & Total \\
\hline Banikoara & 2 & 98 & 100 \\
Kandi & 32 & 68 & 100 \\
Karimama & 25 & 75 & 100 \\
Malanville & 37 & 63 & 100 \\
Total & 96 & 304 & 400 \\
\hline
\end{tabular}

\subsection{Conceptual Structure and Methodology for Estimation}

\subsubsection{Contract Farming Participation and Household Wellbeing}

The choice to adopt a new agricultural production system (contract farming) was modeled on a random utility framework following the works of Becerril et al. [24], Abdulai [25], and Crost et al. [26]. Allow $P^{*}$ to mean the distinction among the usefulness resulting from participating in contract farming $\left(U_{i A}\right)$ and $\left(U_{i N}\right)$, represent the utility from contract farming nonparticipation such that each household will opt to partake in contract farming if $P^{*}=U_{i A}-U_{i N}>0$. Both utilities are unobservable; each can be expressed as a function of observed factors in the latent variable model:

$$
P_{i}^{*}=Z_{i} \alpha+\varepsilon_{i} \text { with } P_{i}=\left\{\begin{array}{l}
1 \text { if } P_{i}^{*}>0 \\
0 \text { otherwise }
\end{array}\right.
$$

where $P$ is a binary 0 or 1 false variable for the use of the new know-how ( $P=1$ if the equipment is accepted and $P=0$ otherwise), $\alpha$ is a trajectory of parameters to be predicted, $Z$ is a vector that stands for domiciliary and farm-level features, and $\varepsilon$ is the random error term.

Participation in contract farming can help increase productivity, farm income, and food security, thus improving household welfare. Assuming that the variable of interest (crop income and food security) is a linear function of a dummy variable for participation in contract farming. This leads to the following equation together with a vector of certain independent variables $(X)$ :

$$
Y_{h}=\gamma X_{h}+\delta P_{h}+\mu_{h}
$$

where $Y_{h}$ signifies the result variables, $\gamma$ and $\delta$ are parameter paths to be determined, $\mu$ is the symbol for error. The strictures $\delta$ are an estimate to evaluate the effect of the involvement in contract farming on the result variable. Nonetheless, if the effect of the contract farming on result variables is to be measured accurately by $\delta$, contracting or noncontracting farmer groups should be assigned randomly to farmers [27].

\subsubsection{Impact Assessment of Participation in Contract Farming}

The assessment of the effect of participation in contract farming on agricultural income and food security based on nonexperimental reflections does not represent a challenge. The outcome variable cannot be observed (agricultural income and food security) for participating farmers in contract farming, otherwise. That is to say, the outcome variables as if had they not participated cannot be observed for families that participate in contract farming (vice versa). Randomly assigning participation in contract farming to treatment and control status, is the way this problem is addressed in experimental research. This ensures that the outcome variables witnessed without participation in control households are statistically characteristic of what would have happened if they had not participated in contract farming. Partaking in contract farming is not a random assignment for the two households groups (contracting and noncontracting farmers) but only for the family itself that chooses to participate in contract farming according to the information available. Consequently, there may be a systematic difference [28] between contracting and noncontracting farmers. 
Most studies [16,28-31] have used a single econometric model, such as correlated random effects (CRE), Tobit, double hurdle, LATE, and other fixed-effect models. The drawback of using a single model is that the estimates are not as robust as each model has its own limitations that cannot be corrected separately. Unlike most studies, our work is unique in that we used the most recent (April 2019) data and two different econometric approaches (LATE and PSM) for impact analysis in Benin.

- $\quad$ The Propensity Score Matching

The PSM technique was used to estimate the causal effects of participation in contract farming. PSM could reduce the bias when comparing the outcomes of farmers participating in contract farming and the nonparticipating group with practically identical features. It is the provisional likelihood of assigning a treatment, given pretreatment specifics [32], designated in this fashion:

$$
P\left(X_{i}\right)=P_{r}\left(L_{i}=1 \mid X_{i}\right)=E\left(L_{i} \mid X_{i}\right)
$$

where $L=[0,1]$ is the gauge of experience with treatment and $X$ is the trajectory of pretreatment features. After projecting the propensity scores, the parameter of interest is the average treatment impact on the treated (ATT), which may be estimated in the following way:

$$
\begin{gathered}
\left.E T T=\left[Y_{i}^{1}-Y_{i}^{0} \mid L_{i}=1, P\left(X_{i}\right)\right]\right\} \\
=E\left\{E\left[Y_{i}^{1} \mid L_{i}=1, P\left(X_{i}\right)\right]-E\left[Y_{i}^{0} \mid L_{i}=0, P\left(X_{i}\right)\right] \| L_{i}=1\right\}
\end{gathered}
$$

with $Y_{i}^{1}$ and $Y_{i}^{0}$, the potential outcomes (the rice income per hectare and the household Food Consumption Score) in two situations are counterfactual.

Despite PSM, the attempt at analyzing the gap among result variables between contract and noncontract farmers have similar characteristics with regard to quantity, the impact of unobservable biases cannot be accounted for due to the fact that it only corrects measurable variables. The hardiness of the impact estimation on outcome variables was checked by combing the LATE parameter with PSM.

\section{- $\quad$ Estimation of the LATE Parameter}

Assessing the impact consists of estimating the situation of contracting farmers on average if they had decided to not participate in CF. A given rice farmer $i$ in this study is considered a contract farming participant if they participate in contract farming for rice production. The results designated for this research was the rice income per hectare and the household Food Consumption Score.

One fundamental way to evaluate the variation between nonadopters and adopters is to define the difference for each specific outcome. Concluding that this relationship is caused by the different methods is problematic. For example, the difficulty was reported by Heckman [33] as owing to the presence of bias in the selection. Moreover, even if there is a positive difference observed between the groups, this does not mean that the relationship is causal. It is likely that the differences existed prior to the adoption decision. To achieve an unbiased result, the two groups must be similar and only have the difference of contract farming adoption. To remedy the selection criteria issue, and to achieve unbiased results, Wooldridge [34] developed experimental and nonexperimental approaches.

Assume that the treatment variable is represented by a binary variable $A_{i}$ indicating the adoption status, with $A_{i}=1$ for adopters and $A_{i}=0$ otherwise. For any farmer $i$, the outcome $y_{i}$ is observed. According to the theory developed by Rubin [35], any farmer $i$ has two potential outcomes, $y_{i 1}$ and $y_{i 0}$, which represent the outcome when the farmer adopted the contract farming system for rice production $\left(A_{i}=1\right)$ or not $\left(A_{i}=0\right)$, respectively. The equation of the outcome $y_{i}$ can be written as:

$$
y_{i}=A_{i} y_{1 i}+\left(1-A_{i}\right) y_{0 i}
$$

The impact of participation in the contract farming system on a farmer $i$ is the difference between the outcome with and without the adoption of the contract farming system $\left(\alpha_{i}=y_{1 i}-y_{0 i}\right)$. However, 
it is impossible to observe this difference in individual farmers since they are either adopters or nonadopters. Therefore, the fundamental problem of impact assessment is that it is impossible to observe $y_{i 1}$ and $y_{i 0}$ simultaneously for a given farmer $i$ [36]. Since observing $y_{i 1}$ or $y_{i 0}$ is possible, the problem of a lack of data arises [34]. This missing value is identified as counterfactual [33]. However, it is possible to measure the effect of treatment for the entire population of rice farmers $\left(E\left(\alpha_{i}\right)\right)$. This is the average treatment effect (ATE). Measuring the ATE on the subpopulations of adopters (ATE1) and nonadopters (ATE0) is also possible [34].

Rosenbaum [37] and Lee [38] reported that the ATE, ATE1, and ATE0 parameters are subject to two types of bias. The first is related to the difference between the observable characteristics (overt bias) and the second is related to the difference between the unobservable characteristics (hidden bias), which affect farmers' access to information and their decision regarding whether to adopt innovations.

To correct the biases induced by observable and unobservable characteristics, Imbens and Angrist [39] proposed another estimator called, the local average treatment effect (LATE), which is the average impact on potential contracting farmers (compliers). To evaluate this estimator, an instrumental variable approach must be used [40]. This approach assumes the presence of the instrumental variable $z$ that directly affects the status of the participation in contract farming but implicitly affects the result variables $y_{1}$ and $y_{0}$ until independent variables $(x)$ are regulated.

In this study, the instrumental variable ( $z$ ) used was the contract farming knowledge. Then, for any rice farmer who knows the contract farming system, $z=1$, and $z=0$ otherwise. We chose this variable because information has an impact on the decision as to whether to participate in contract farming. Therefore, farmers with knowledge on the contract farming system only are able to participate in contract farming. Knowledge cannot, however, only directly affect the outcome. Then, rice-producing is a valid instrument and fulfills Heckman's [33] interpretation of the instrumental variable.

In this analysis, Abadie's [40] suggested estimator was used to estimate the LATE parameter.. This estimator is a generalization of the first one proposed by Imbens and Angrist [39], for which the random nature of the instrument is not required, but the instrument $z$ must be independent of $y_{1}$ and $y_{0}$, conditionally to $x$. The local average response function (LARF) model is defined as:

$$
\begin{gathered}
E\left(y \mid x, A_{1}=1\right)=\alpha_{0}+\alpha_{1} A+\beta X+\gamma A X \\
\operatorname{LAT\hat {E}_{LARF}}=\frac{1}{p\left(A_{1}=1\right)} \sum_{i=1}^{n_{1}} \hat{k}_{i} \cdot h\left(y_{i}, x_{i}, \hat{\theta}\right) .
\end{gathered}
$$

- Calculation of Food Consumption Score (FCS)

The examination of food security situation of rice farmers was focused on the FCS, which was established as a composite indicator by the World Food Program (WFP) [41].

This calculation is generally achieved by including the dietary range of the household, how often, and the relative nutritional value of that which is eaten in a specific household. There are eight food groups that are considered in the calculation of the FCS, each with a weighted frequency (cereals and tubers, pulses, vegetables, fruit, meat and fish, milk, sugar, and oil) through seven days earlier the investigation (Table 2). The weighted range of the FCS is from 0 to 112. A one-week recall is suggested to make sure that time coverage is good and that memory is reliable [42]. The following food groups are the basis of the FCS calculation.

$$
\begin{array}{rr}
\text { FCS }=P_{\text {Cereal }} X_{\text {Cereal }}+P_{\text {Legumes }} X_{\text {Legumes }}+P_{\text {Vegetables }} X_{\text {Vegetables }}+P_{\text {Fruits }} X_{\text {Fruits }}+ \\
& P_{\text {Proteins }} X_{\text {Proteins }}+P_{\text {Milk }} X_{\text {Milk }}+P_{\text {Sugar }} X_{\text {Sugar }}+P_{\text {Oil }} X_{\text {Oil }}
\end{array}
$$

where $P_{i}$ is the weight assigned to a given food group and $X_{i}$ is the number of days of consumption of a given food group ( $\leq 7$ days). 
Table 2. Food groups and weights for the estimation of Food Consumption Score (FCS).

\begin{tabular}{ccc}
\hline Food Items & Food Group & Weight \\
\hline $\begin{array}{c}\text { Maize, rice, sorghum, millet, pasta, bread cassava, } \\
\text { potatoes, sweet potatoes, and other cereals and tubers }\end{array}$ & Main staples & 2 \\
\hline Beans, peas, groundnuts, and cashew nuts & Pulses & 3 \\
\hline Vegetables and leaves & Vegetables & 1 \\
\hline Fruits & Fruit & 1 \\
\hline Beef, goat, poultry, pork, eggs, and fish & Meat and Fish & 4 \\
\hline Milk, yogurt, and other diaries & Milk & 4 \\
\hline Sugar and sugar products & Sugar & 0.5 \\
\hline Oils, fats, and butter & Oil & 0.5 \\
\hline Source World Food Program $[41]$
\end{tabular}

Source: World Food Program [41].

The calculated values of FCS for each household range on a scale from 0 to 112. The WFP distinguishes three groups according to the FCS values (scale from 0 to 112). The first group of households having an FCS less than 21 qualifies as a household having poor food consumption because the quantity and nutritional quality of food consumed are inadequate. The second group of households, where the FCS is between 21.5 and 35, has middle food consumption because they have the required nutritional food quality, but the quantity is not adequate to feed all members of the household. Finally, the third group includes households living in food security. All members of these households consume food within the required quantity and nutritional quality range; their FCS is higher than 35 .

The explanation of variables employed in the study are itemized in Table 3.

Table 3. Description of the variables used in the study.

\begin{tabular}{|c|c|c|c|}
\hline Variable & Description & Unit of Measure & Expected Sign \\
\hline \multicolumn{4}{|l|}{ Dependent Variable } \\
\hline Contract farming participation & $\begin{array}{l}\text { Participation of respondent in contract farming or } \\
\text { not }\end{array}$ & Dummy: $\mathrm{No}=0$ and $\mathrm{Yes}=1$ & $+/-$ \\
\hline \multicolumn{4}{|l|}{ Explanatory variables } \\
\hline Age & Age of household head (Years) & Years & $+/-$ \\
\hline Family size & Number of people in the household & Continuous & $+/-$ \\
\hline Gender & Sex of household head (Dummy) & Dummy: Male $=1$ and Female $=0$ & $+/-$ \\
\hline Marital status & The respondent is married or not & Dummy: No $=0$ and $Y e s=1$ & $+/-$ \\
\hline Education & The respondent has education or not & Dummy: No $=0$ and $Y e s=1$ & $+/-$ \\
\hline Member of farmers group & The respondent is member of farmer group or not & Dummy: No $=0$ and Yes $=1$ & + \\
\hline Rice quantity produced & Rice quantity produced by the respondent $(\mathrm{Kg})$ & Kilograms & + \\
\hline Rice cultivated area & Land planted with rice & Hectare & $+/-$ \\
\hline Rice sales price & $\begin{array}{l}\text { Sales price per kilogram of rice produced by the } \\
\text { respondent (XOF) }\end{array}$ & Continuous & $+/-$ \\
\hline Off-farm income & The respondent has off-farm income or not & Dummy: No $=0$ and $Y e s=1$ & $+/-$ \\
\hline \multicolumn{4}{|l|}{ Land inheritance } \\
\hline Existence of the market in the area & Existence of the market in the study area or not & Dummy: No $=0$ and $Y e s=1$ & $+/-$ \\
\hline Rice income per ha & $\begin{array}{l}\text { Income per hectare from respondent rice } \\
\text { production }\end{array}$ & Continuous & $+/-$ \\
\hline Food Consumption Score (FCS) & $\begin{array}{l}\text { Food Consumption Score of the respondent } \\
\text { household }\end{array}$ & Score & $+/-$ \\
\hline
\end{tabular}

Note: "+/- "designates the predictable sign could be either positive or negative.

\section{Results and Discussion}

\subsection{Quality of the Matching Process}

Before addressing the causal result of involving farmers in contract farming efforts on their income and food security, quality assessment resulting from the matching test was first. We estimated the propensity scores for both types of farms (participating and nonparticipating) and tested the common 
support condition. Table 4 reveals that there was a range of forecast propensity scores for participants which varied from 0.079 to 0.969 ; the average was 0.37 . The range of forecast propensity scores for nonparticipants averaged 0.24 and varied from 0.051 to 0.802 .

Table 4. Logit estimates of the determinants of contract farming participation in the Alibori Department.

\begin{tabular}{|c|c|c|}
\hline Variable & Coefficient & z-Value \\
\hline Age of head of household (Years) & -0.014 & -0.86 \\
\hline Family size (Continuous) & 0.018 & 0.33 \\
\hline Gender (Dummy) & 1.100 & 1.32 \\
\hline Marital status (Dummy) & -0.364 & -0.43 \\
\hline Education (Dummy) & 0.128 & 0.36 \\
\hline Member of farmer group (Dummy) & $0.880 * *$ & 2.14 \\
\hline Rice quantity produced $(\mathrm{Kg})$ & 0.000 & 0.33 \\
\hline Rice cultivated area $(\mathrm{Ha})$ & $0.524^{* * *}$ & 2.83 \\
\hline Rice sales price (FCFA) & 0.005 & 0.93 \\
\hline Off-farm income (Dummy) & -0.145 & -0.27 \\
\hline Constant & $-3.479 * *$ & -2.25 \\
\hline \multicolumn{3}{|c|}{ Summary statistics } \\
\hline Pseudo $R^{2}$ & \multicolumn{2}{|c|}{0.103} \\
\hline Prob $>\chi^{2}$ & \multicolumn{2}{|c|}{$0.005^{* * *}$} \\
\hline Likelihood-ratio $\chi^{2}(10)$ & \multicolumn{2}{|c|}{25.09} \\
\hline Participant correctly predicted & \multicolumn{2}{|c|}{$37 \%$} \\
\hline Nonparticipant correctly predicted & \multicolumn{2}{|c|}{$24 \%$} \\
\hline Number of observations & \multicolumn{2}{|c|}{208} \\
\hline
\end{tabular}

Consequently, the minimal and maximal assessment was used to support the accepted value of 0.061-0.970 for the area. Common support for the propensity scores (Figure 3) is also evidenced as the distribution density of the density distribution of the projected propensity values: The overlap between the participation's cores for participants and nonparticipants alike is substantive (Figure 3).

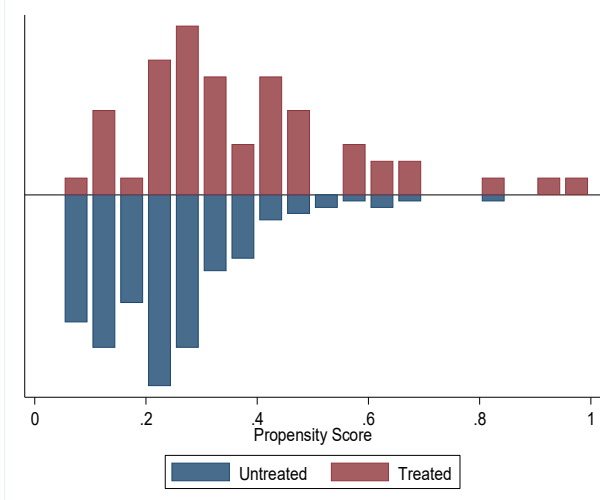

(a)

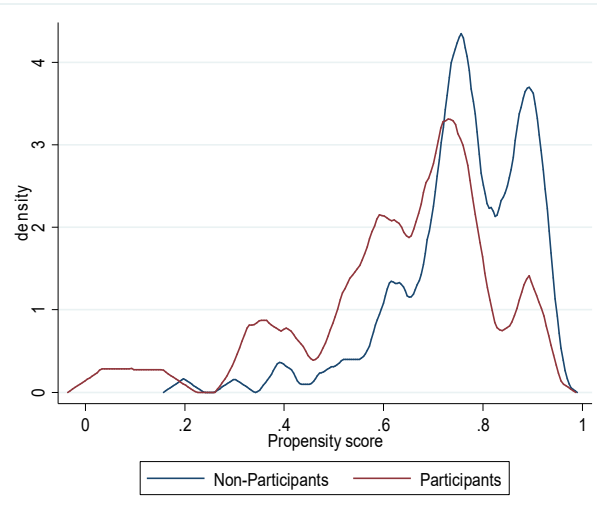

(b)

Figure 3. Propensity score distribution and common support for propensity score estimation. (a) The propensity score distribution; (b) the common support for the propensity score estimation.

Following Bravo-Ureta et al. [42], $\mathrm{t}$-tests were performed before and after matching to assess the null hypothesis that the means of the observed characteristics of participants and nonparticipants in contract farming are equal. The results showed that the mean of most of the observed characteristics was not statistically different, suggesting that the balancing property of the covariates was also satisfied. Table 5 presents the descriptive statistics for the unmatched $(N=400)$ and matched $(N=208)$ samples and the results of the $t$-tests. 
Table 5. Descriptive statistics.

\begin{tabular}{|c|c|c|c|c|c|c|c|}
\hline \multirow{2}{*}{ Variable } & \multicolumn{2}{|c|}{ Noncontract (Control) } & \multicolumn{2}{|c|}{ Contract Farmers } & \multicolumn{2}{|c|}{ All Farmers } & \multirow{2}{*}{ Test of Means a } \\
\hline & Mean & SD & Mean & SD & Mean & SD & \\
\hline \multicolumn{8}{|c|}{ Unmatched sample } \\
\hline Age of head of household (Years) & 47.786 & 12.501 & 48.125 & 10.803 & 47.868 & 12.104 & 0.239 \\
\hline Family size (Continuous) & 7.727 & 4.067 & 7.540 & 3.860 & 7.682 & 4.013 & 0.394 \\
\hline Gender (Dummy) & 0.845 & 0.362 & 0.885 & 0.320 & 0.855 & 0.353 & 0.970 \\
\hline Marital status (Dummy) & 1.618 & 1.791 & 1.510 & 1.666 & 1.593 & 1.760 & 0.524 \\
\hline Education (Dummy) & 0.507 & 0.501 & 0.563 & 0.499 & 0.520 & 0.500 & 0.955 \\
\hline Member of farmer group (Dummy) & 0.615 & 0.487 & 0.781 & 0.416 & 0.655 & 0.476 & $3.011^{* * *}$ \\
\hline Rice quantity produced $(\mathrm{Kg})$ & 800.284 & 1012.435 & 1320.828 & 1544.353 & 953.809 & 1213.9 & $2.931^{* * *}$ \\
\hline Rice cultivated area (ha) & 0.813 & 0.952 & 1.230 & 1.288 & 0.912 & 1.050 & $3.216^{* * *}$ \\
\hline Rice sales price (FCFA) & 200 & 0.000 & 208.438 & 64.356 & 202.025 & 31.609 & $2.292 * *$ \\
\hline Off-farm income (Dummy) & 0.161 & 0.368 & 0.114 & 0.320 & 0.15 & 0.358 & 1.114 \\
\hline Observations $(N)$ & \multicolumn{2}{|c|}{304} & \multicolumn{2}{|c|}{96} & \multicolumn{2}{|c|}{400} & \\
\hline \multicolumn{8}{|c|}{ Matched sample } \\
\hline Age of head of household (Years) & 46.470 & 12.567 & 45.526 & 10.830 & 46.212 & 12.098 & 0.501 \\
\hline Family size (Continuous) & 7.563 & 3.475 & 8.018 & 3.467 & 7.688 & 3.470 & 0.842 \\
\hline Gender (Dummy) & 0.854 & 0.354 & 0.912 & 0.285 & 0.870 & 0.337 & 1.108 \\
\hline Marital status (Dummy) & 1.510 & 1.628 & 1.333 & 1.354 & 1.462 & 1.557 & 0.729 \\
\hline Education (Dummy) & 0.550 & 0.499 & 0.632 & 0.487 & 0.572 & 0.496 & 1.063 \\
\hline Member of farmer group (Dummy) & 0.656 & 0.477 & 0.825 & 0.384 & 0.702 & 0.459 & 2.397 \\
\hline Rice quantity produced (Kg) & 808.897 & 1016.208 & 1225.14 & 1604.486 & 922.964 & 1216.306 & 2.222 \\
\hline Rice cultivated area (ha) & 0.698 & 0.759 & 1.338 & 1.496 & 0.873 & 1.051 & 4.061 \\
\hline Rice sales price (FCFA) & 200 & 0.000 & 213.597 & 64.336 & 203.726 & 34.010 & 2.607 \\
\hline Off-farm income (Dummy) & 0.139 & 0.347 & 0.105 & 0.310 & 0.130 & 0.337 & 0.645 \\
\hline
\end{tabular}

${ }^{a}$ The $t$-test was used to determine whether the means of sampling are significantly different between contract farmers and noncontract farmers groups; ${ }^{* *} p<0.05, * * * p<0.01$. 
Once the matched samples were obtained, we estimated the LATE parameters to reveal the impact of contract farming on income and food security.

\subsection{Participation in Contract Farming (Adoption)}

The overall potential participation rates in contract farming within the subpopulation of those who know and those who do not know about contract farming are presented in Table 6.

Table 6. Participation rate in contract farming.

\begin{tabular}{|c|c|c|}
\hline Parameters & Values & $\begin{array}{c}\text { Robust } \\
\text { Standard Deviation }\end{array}$ \\
\hline Potential participant rate (ATE) & $0.532 * * *$ & 0.049 \\
\hline $\begin{array}{l}\text { Rate of participants within farmers population informed } \\
\text { about the contract farming (ATE1) }\end{array}$ & $0.618^{* * *}$ & 0.039 \\
\hline $\begin{array}{l}\text { Rate of participants in farmers population not informed } \\
\text { about the contract farming (ATE0) }\end{array}$ & $0.464^{* * *}$ & 0.068 \\
\hline Actual participation rate in all population (JEA) & $0.273^{* * *}$ & 0.017 \\
\hline Rate of participants in all population $(\mathrm{Na} / \mathrm{N})$ & $0.274^{* * *}$ & 0.031 \\
\hline $\begin{array}{l}\text { Rate of farmers who know the contract farming in all } \\
\text { population }(\mathrm{Ne} / \mathrm{N})\end{array}$ & $0.442^{* * *}$ & 0.034 \\
\hline $\begin{array}{l}\text { Deviation of participation in contract farming }(\mathrm{GAP}= \\
\qquad \mathrm{Na} / \mathrm{N}-\mathrm{ATE})\end{array}$ & $-0.259 * * *$ & 0.038 \\
\hline Selection bias $(\mathrm{PSB}=\mathrm{ATE} 1-\mathrm{ATE})$ & $0.086^{* * *}$ & 0.033 \\
\hline Number of Observation (N) & & 208 \\
\hline Number of exposed (Ne) & & 92 \\
\hline Number of participants in the contract $(\mathrm{Na})$ & & 57 \\
\hline
\end{tabular}

${ }^{* * *} p<0.001$.

The potential participation rate within the whole population, estimated by the semi-parametric method of the respondents, is high (53\%), compared to the actual participation rate within the whole population (join exposure and participation (adoption) rate) which is $27 \%$; there is, therefore, a participation gap (population participant gap linked to incomplete dissemination) which is $-26 \%$. Additionally, the rate of participants within farmers population informed about contract farming (ATE1) and the rate of participants in farmers population who are not informed about contract farming (ATE0) are $62 \%$ and $46 \%$, respectively; which would mean that about $46 \%$ of uninformed producers would participate in contract farming if they were informed. In addition, any farmers in the population can participate in contract farming in the same way as farmers in the subpopulation were informed about contract farming. Indeed, as shown by Diagne [36] in his study on methods for estimating the average treatment effect, PSB = ATE1-ATE. Thus, the statistical significance of PSB implies the acceptance of the hypothesis ATE1-ATE $\neq 0$. Efforts, therefore, remain to be made in order to achieve full dissemination of contract farming and the massive participation of farmers, but while taking reassurance that the contractual system implemented in the area will positively affect farmers well-being; otherwise, participation will always remain mixed and the existence of the contract farming system in the community will remain of little importance for farmers.

\subsection{Impact of Contract Farming on Farmer Income per Hectare and Food Security}

The LATE was estimated using the instrumental variable approach. The instrument used was the knowledge of contract farming. Impact estimate results are reported in Table 7 . We found evidence of negative significant effects of contract farming on rice production income at a $1 \%$ threshold. These results showed that the more rice farmers participate in contract farming, the lower the farm income. This means that the return to crop production in the study area is decreasing; and can be explained by, the lack of access to good quality seeds and low mastery of the technical routes of production 
and fertilizer application, as well as climatic disturbances. The contracting farmers once contracted do not normally have the choice to deliver their products to the one with whom the contract was signed. Therefore, due to climatic disturbances and low yields obtained, even if the selling price on the market is more profitable for the contracting farmers, he has no choice and he will not be able to benefit from this price advantage that the market offers him. Contracting farmers are obliged to deliver the product as agreed according to the terms of the contract to avoid conflict situations because, in the contract, the purchase price is fixed in advance. On the other hand, noncontracting farmers can benefit from this time-lapse from this market price advantage and suddenly will be cheaper than contracting producers. Therefore, even if the contracting farmers make a higher income than the noncontracting farmers, the difference in income between the two types of farmers would be significant if the price offered to the contracting farmers could be renegotiated in accordance with the market price while taking into account, of course, the other benefits they would receive such as the suppression of the logistic price. This explanation is in line with the results of our studies; on average, the rice income per hectare of contracting rice farmers (West African CFA franc (XOF) 216,359.30) is higher than those of noncontracting farmers (XOF 142,398.10), but the difference (XOF 73,961.24) is not significant. We can deduce that contract farming is not yet a panacea that improves farmers' income if it is not properly configured. Therefore, it is difficult to claim that all contract farming increases participants' income, as claimed by some studies [13,43-45]. Looking at international studies, up to a point, these results reflect Glover et al. [46], who reported that contract farmers have lower incomes than noncontracting farmers, suggesting that farmers could earn more growing other crops for other markets. In the case of an unsatisfactory yield from the main rice crop, income from other crops could offset the gap.

Table 7. Impact results on rice income and food security.

\begin{tabular}{ccc}
\hline $\begin{array}{c}\text { Parameter } \\
\text { Local Average Response Function } \\
\text { (LARF-OLS) }\end{array}$ & Estimates & $\mathbf{Z}$ \\
\hline Rice income per ha (XOF) & \\
\hline Local Average Treatment Effect & $-26,145.72^{* * *}$ & $-4.1 \times 10^{6}$ \\
\hline Naïve Method & \\
Difference & $73,961.24$ & 1.41 \\
Contract farmers & $216,359.30^{* * *}$ & 4.23 \\
Noncontract & $142,398.10^{* * *}$ & 12.34 \\
\hline Food Consumption Score $(\mathrm{FCS})$ & \\
\hline Local Average Treatment Effect & $-60.64^{* * *}$ & -8153.96 \\
\hline Naïve Method & -1.42 & -0.25 \\
Difference & $49.23^{* * *}$ & 11.16 \\
Contract farmers & $50.65^{* * *}$ & 14.78 \\
Noncontract &
\end{tabular}

Douroux [47] reported that farmers do not improve their incomes if they only deliver raw products. The transformation of the product, much more than production itself, provides its value. However, the contractual economy risks trapping peasants in their function as farmers, just like a supplier of raw materials. Douroux's recommendation seems to be relevant to our findings because many farmers after contracting are often confronted with conflicts of interest (Table 8) that affect the economy of their production. The reasons for these conflicts are, among others, nonadherence to the terms of the contracts and the moral hazard observed by some farmers against the unprofitable selling price. Other producers almost experience a decline in sales and a deterioration of their products in stock, 
which result in production losses. If farmers had the right tools to directly process their product, farm incomes would improve.

Table 8. Share of contracting farmers who experienced conflicts in contract implementation.

\begin{tabular}{|c|c|c|c|}
\hline \multirow{2}{*}{ Contract } & \multicolumn{2}{|c|}{ Conflict } & \multirow{2}{*}{ Total } \\
\hline & No & Yes & \\
\hline No & 151 & 0 & 151 \\
\hline Yes & 31 & 26 & 57 \\
\hline Total & 182 & 26 & 208 \\
\hline
\end{tabular}

Evidence of the negative effects of contract farming on the FCS was also found (-60.64), which was significant at the $1 \%$ level, which shows that the more rice farmers participate in contract farming, the lower the FCS. The estimated impact of the FCS was below 21, which qualifies as a household having poor food consumption because the quantity and nutritional quality of the food consumed are inadequate. This means that, contrary to existing studies reporting the positive impact of contract farming on food security, our results show that contract farming decreased participating farmers' household food and nutrition security. This implies that not only do contracting farmers only devote their time to production to satisfy the contract market to the point where they no longer produce for subsistence, but they also produce products that are not part of the eating habits of the region. The substitution effects due to higher shadow food prices outweigh the revenue effects of crop sales under contract farming participation. These results are consistent with findings of Proscovia et al. [48] and Kenneth [49], who investigated the effects of market production on rural household food consumption in Uganda and the impact of contracted sugarcane farming on household food security in Uriri Division, Kenya, respectively. They reported the negative impact of contract farming on the household food security of contracting farmers. A mixed approach combining policies targeted at market products, as well as production for private consumption and nutrition sensitization could be profitable for contracting farmers.

\subsubsection{Determinant of Rice Farmers' Income Per Hectare}

Among the determinants of producer income presented in Table 9, the negative and insignificant result of the contract participation variable is not surprising since the impact was negative. Household size, heritage, rice sales price, existence of the market in the study region, and the age of head of household are the variables that explain rice production income. The results showed that the age of the head of household is negatively correlated with rice production income per hectare at a significance level of $1 \%$. This means that the older the producers, the lower their ability to produce efficiently and over time. Older producers may not be able to strictly apply production routes, which could influence the final quality of the obtained rice and result in poor sales and low income.

By classifying the farmers surveyed according to the classification of young and adult populations of the United Nations [50], we confirmed with Figure 4 our results in Table 9 that age has a negative influence on agricultural income due to the decline in income observed among respondents aged 50 years and over; the trend is positive until the age of 50 years and that, whether with contracting farmers than noncontractor. This results is consistent with that of Aminou [41], which finds that older producers would be more conservative so that they want to continue with their habits, customs of production. 
Table 9. Local Average Response Function-Ordinary Least Square regression (LARF-OLS) of the determinant of rice production income per hectare.

\begin{tabular}{ccc}
\hline Variable & Coefficient & SD \\
\hline Contract & $-26,145.72$ & $47,549.06$ \\
Family size & $18,357.04^{* * *}$ & 6349.58 \\
Land inheritance & $70,645.47^{*}$ & $35,611.35$ \\
Rice sales price & $7144.532^{* * *}$ & 2546.025 \\
Existence of the market in the area & $363,221.1^{* * *}$ & $114,240.1$ \\
Age of head of household & $-4764.285^{* * *}$ & 1406.375 \\
Constant & $-1,181,288^{* *}$ & $519,955.5$ \\
F $(6,79)$ & \multicolumn{3}{c}{3.77} \\
Prob $>F$ & \multicolumn{2}{c}{0.0024} \\
Adj $R$-squared & \multicolumn{2}{c}{86} \\
Number of observations & \multicolumn{2}{c}{} \\
\hline
\end{tabular}

${ }^{*} p<0.1,{ }^{* *} p<0.05,{ }^{* * *} p<0.01$.

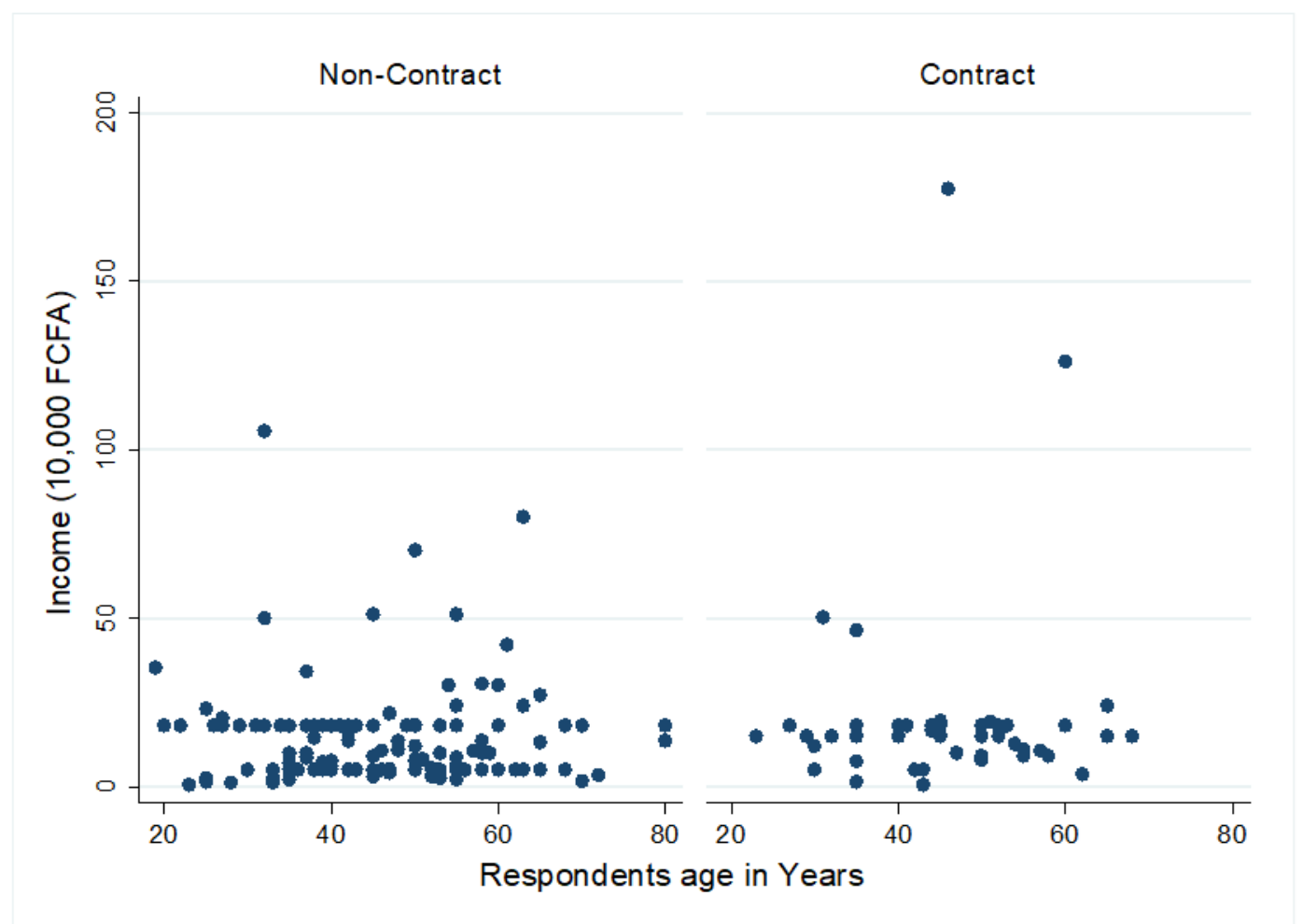

Figure 4. Repartition of respondents' income by age group and participation in contract farming.

Agricultural production is not benefitted by an increase in age of the farmers. An increase in age does not increase agricultural output. The expertise and knowledge of the aged farmer does (Figure 5) not really balance the negative limitation of their age. Moreover, aged farmer workers do not readily adapt to the newer technology employed in farming. This result agrees with Guo et al. [51], whose work similarly analyzed the result of the age of farmers on agriculture. 


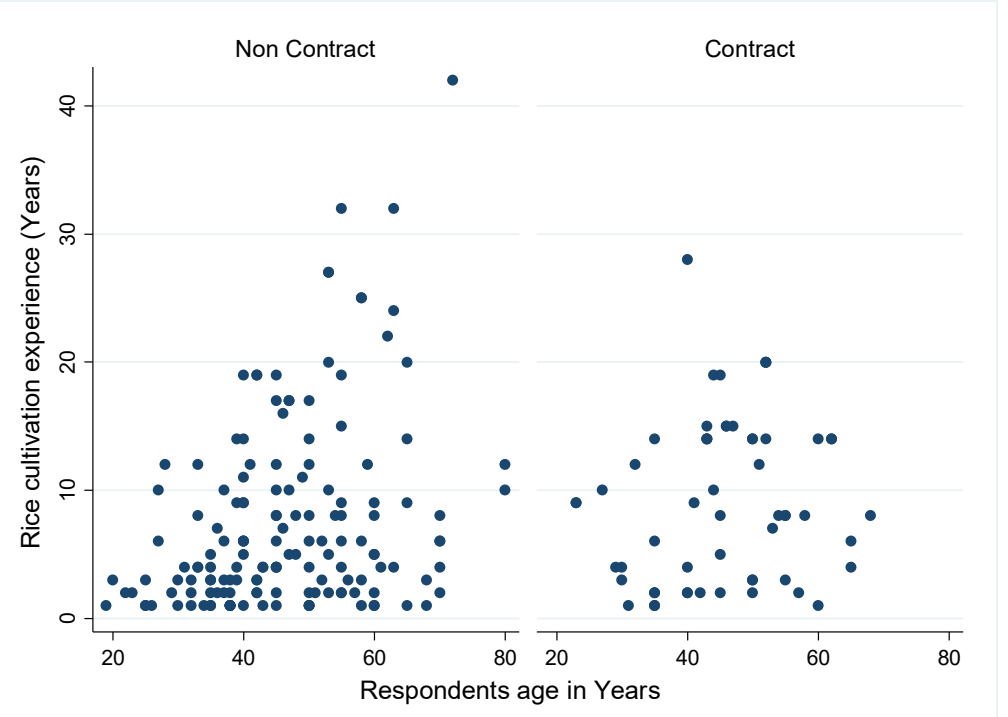

Figure 5. Rice cultivation experience of respondents by participation in contract farming.

\subsubsection{Determinant of Rice Farmer Household Food Security}

All variables included in this model (Table 10) were those explaining the household food security in the area study. Some positively influenced food security, others did not. The coefficient of the contract variable was negative and significant at the $1 \%$ level. This means that the more farmers participate in contract farming, the lower their food security level. This can be explained by farmers, in focusing on production to satisfy only the contract market, do not produce what is necessary for subsistence to the point where they have a low household FCS. Even if they plan to procure the necessary food with the income from production, a market failure or high food prices can hinder farmers from obtaining the necessary food for their households. As the coefficient of the rice sales price variable was also negative and significant at the $1 \%$ level, a weak market exists because the lower the market price, the lower the income. As a result, their low purchasing power does not allow them to obtain and store on quality food products to guarantee an acceptable level of food security for their household. Our result is consistent with those reported by Dzramedo et al. [52]. This suggests that farmers, to increase their farm income and food security, need support in increasing the levels of farm inputs, such as land, labor, and fertilizers.

Table 10. Local Average Response Function-Ordinary Least Square regression (LARF-OLS) of the determinant of household food security.

\begin{tabular}{ccc}
\hline Variable & Coefficient & SD \\
\hline Contract (Dummy) & $-60.636^{* * *}$ & 9.865 \\
Family size (Continuous) & $4.682^{* * *}$ & 0.909 \\
Land inheritance (Dummy) & $40.133^{* * *}$ & 6.771 \\
Rice sales price (FCFA) & $-1.239^{* * *}$ & 0.419 \\
Existence of the market in the area (Dummy) & $339.491^{* * *}$ & 27.596 \\
Age of head of household (Years) & $-2.676^{* * *}$ & 0.276 \\
Nonagricultural activities income (Dummy) & $231.284^{* * *}$ & 19.025 \\
Constant & $333.373^{* * *}$ & 85.004 \\
\hline F (7,66) & \multicolumn{2}{c}{24.44} \\
Prob $>$ F & \multicolumn{2}{c}{0.0000} \\
Adj $R^{2}$ & \multicolumn{2}{c}{74} \\
Observations & \multicolumn{2}{c}{} \\
\hline
\end{tabular}


The household size denotes the intensity of rice cultivation in terms of labor. This variable had a positive influence on the FCS of farmers. The coefficient of farm size (4.682) means that if the household size increased by one unit, holding all other inputs constant, the food security of farmers would increase by 4.682 units. The size of a farmer's household denotes higher investments; thus, farmers attempt to reduce their risk coverage by participating in contracts in the hope of good economic profitability, as well as an improvement in their food security from their work efforts.

Similarly, land inheritance positively affects farmers' food security. The coefficient of this variable was positive and statistically significant at the $1 \%$ level. Thus, the inheritance of land, by offering farmers a long-term stake in land, reduces the production costs or the capital of the producer so it can be exploited for other purposes. Land is an important resource base for a farmer in the production process. The economic and social progress of farmers depends mostly on the size of their cultivated area. Farmers with more arable land are less likely to be involved in contract farming before achieving a good level of food security. Our finding is in line with that of Just et al. [53].

The existence of a market in the area remains an opportunity for commercial exchange and supply of household food products for farmers. At the level of $1 \%$ the coefficient of the existence of market variable was positive and significant. This ensures that the more markets exist, the greater the availability of consumable food for households in the area; therefore, farmers with the resources to acquire food will be able to access it without difficulty. These results agree with those of Kousar et al. [32], who investigated the impacts of fruits on farmers' work in Pakistan Himalayan Range.

Lastly, the positive coefficient observed for the nonagricultural activities income variable means that, in general, a farmer who has other sources of income may not want to engage in contract farming due to its related difficulties, such as contracting companies offering lower rates for farmers' produce. However, the results suggest that even though off-farm income provides extra income, its associated factors may differ in relation to contract farming, and the more that farmers have income from extra activities, the less the propensity they have to participate in CF. Concerning the sale market constraint, farmers may consider contract farming if the sale price is suitable. From an off-farm income, farmers can ensure acceptable food security in their household.

\section{Conclusions and Policy Implications}

In this study, we analyzed the impact of contract farming on smallholder rice farmers' income and food security in Benin (Alibori Department). The results showed significant negative impacts from participation in contract farming. The more that rice farmers participate in contract farming, the lower their income and food security level. Contract farming is, therefore, not a reasonable policy instrument that can help farmers increase their income and improve their food security in the Department of Alibori. The necessary resources and economic environment are not yet in place to allow farmers to take full advantage of the potential benefits of contract farming. To avoid the risk of wasting scarce public resources, contract farming should not be expanded in marginal areas with markets and other infrastructure. Additional measures are needed for contract farming to be truly profitable for those involved and to ensure sustainability and the large-scale participation of farmers.

In connection with the main results of this study, the following measures are recommended:

(1) Focus on improving the agricultural productivity of existing land in contract terms due to the extreme land constraints faced by smallholders and the restricted (Political) scope of agrarian reform in Benin.

(2) Ensure access to good-quality seeds and secure the production of certified seeds. Several structures produce and sell seeds, there are even seed producers who supply seed to farmers. However, the quality of its seeds remains questionable in view of the mixed production yields that we observe. A seed certification under quality check condition could allow producers to know how to better choose good seeds.

(3) Provide operational training on the technical routes of production and fertilizer application techniques in contract terms. The operation training will strengthen the capacities of the producer 
on the production routes and application of fertilizers in order to ultimately achieve a good production yield.

(4) Improve the yield and drought resistance of rice varieties by investing more in agricultural research. With the resistant varieties, producers will be able to avoid the smallest losses recorded in the face of climatic disturbances and achieve production with good yield.

(5) The terms of the contract should include a policy that may enable both contracting parties to avoid conflicts.

(6) Define for contract farming implementation a policy specific to each region.

To our knowledge, we are the only ones to have combined the PSM and LATE approach for a socio-economic impact assessment of contract farming. We do not think that our method, robust in any way it is, will be eternal. There probably exists in the future more robust methods that can provide other interesting evidence as ours found today. However, future research studies should investigate if contract farming alleviates poverty and how to help farmers and buyers to realize a win-win contract farming situation without conflict.

Author Contributions: Conceptualization, O.A.O.; Methodology, O.A.O., D.A.; Validation, G.-C.L., S.E.H.K., and G.B.; Investigation, O.A.O.; Resources, G.-C.L.; Data curation, O.A.O., K.A.A.A.; Writing-original draft preparation, O.A.O.; Writing-review and editing, O.A.O.; S.E.H.K., D.A., and F.V.D.; Supervision, G.-C.L.; Funding acquisition, G.-C.L. All authors have read and agreed to the published version of the manuscript.

Funding: This project is supported by the National Natural Sciences Foundation of China (NSFC N ${ }^{\circ}$. 71873050).

Acknowledgments: The authors gratefully acknowledge the College of Economics and Management, Huazhong Agricultural University, and the National Natural Sciences Foundation of China (NSFC) for funding this research. The authors are very grateful to the anonymous reviewers and the editor for their insightful comments. The views expressed in this paper are the sole responsibility of the authors.

Conflicts of Interest: The authors declare no conflict of interest.

\section{References}

1. Smith, A. Wealth of Nations. In The Wealth of Nations; Capaldi, N., Lloyd, G., Eds.; John Wiley \& Sons, Inc.: Hoboken, NJ, USA, 2011; pp. 109-160. ISBN 978-1-118-01169-0.

2. Abdullah; Rabbi, F.; Ahamad, R.; Ali, S.; Chandio, A.A.; Ahmad, W.; Ilyas, A.; Din, I.U. Determinants of commercialization and its impact on the welfare of smallholder rice farmers by using Heckman's two-stage approach. J. Saudi Soc. Agric. Sci. 2017, 18, 224-233. [CrossRef]

3. Arouna, A.; Adegbola, P.V.; Zossou, R.C.; Babatunde, R.; Diagne, A. Contract Farming Preferences of Smallholder Rice Producers in Benin: A Stated Choice Model Using Mixed Logit. Tropicultura 2017, 35. [CrossRef]

4. $\quad$ Konnon, D.-D.; Sotondji, C.S.; Adidehou, Y.A. Rapport Final Rapport de L'etude D'etat des Lieux de la Filiere riz au Benin en 2014; Conseil de concertation des riziculteurs du enin: Bohicon, Benin, 2014.

5. Vigné, F. Riz du Bénin, Riz de Demain. Fiche Pédagogique, CCRB-CIDR-ETD; ALIMENTERRE: Paris, France, 2011.

6. FAO. Contract Farming for Inclusive Market Access; FAO: Rome, Italy, 2013; ISBN 9789251080610.

7. Eaton, C.; Shepherd, A.W. Contract Farming Partnerships for Growth; Food and Agricultural Organisation of the United Nations: Rome, Italy, 2001.

8. World Bank. Agriculture for Development 2008 World Development Report; World Bank: Washington, WA, USA, 2007.

9. Bolwig, S. Poverty and Gender Effects of Smallholder Organic Contract Farming in Uganda. International Food Policy Research Institute; APA: Washington, DC, USA, 2012.

10. Warning, M.; Key, N. The social performance and distributional consequences of contract farming: An equilibrium analysis of the arachide de bouche program in Senegal. World Dev. 2002, 30, 255-263. [CrossRef]

11. Otsuka, K.; Nakano, Y.; Takahashi, K. Contract Farming in Developed and Developing Countries. Annual Rev. Resour. Econ. 2016, 8, 353-376. [CrossRef]

12. Igweoscar, O. Effect of Contract Farming on Productity and Welfare of Cassava-Based Farmers in South Eastern Nigeria. Eur. J. Bus. Manag. 2014, 6, 2222-2839. 
13. Ton, G.; Vellema, W.; Desiere, S.; Weituschat, S.; Haese, D. Development Review Contract farming for improving smallholder incomes: What can we learn from effectiveness studies? World Dev. 2018, 104, 46-64. [CrossRef]

14. Bellemare, M.F. As You Sow, So Shall You Reap: The Welfare Impacts of Contract Farming. World Dev. 2012, 40, 1418-1434. [CrossRef]

15. Maertens, M.; Vande, K. Contract farming in staple Food Chains: The Case of Rice in Benin. World Dev. 2017, 95, 73-87. [CrossRef]

16. Wainaina, P.W.; Okello, J.J.; Nzuma, J.M. Blessing or Evil? Contract Farming, Smallholder Poultry Production and Household Welfare in Kenya. Q. J. Int. Agric. 2014, 53, 319-340.

17. Maertens, M.; Swinnen, J.F.M. Trade, Standards, and Poverty: Evidence from Senegal. World Dev. 2009, 37, 161-178. [CrossRef]

18. Gandonou, E.A.; Chogou, S.K.; Adegbidi, A.B.E.A.; Fafeh, A.E.K. Contrats agricoles informels et performance de la production vivrière: Cas du maïs au sud du Bénin. Tropicultura 2019. Available online: https: //popups.uliege.be/2295-8010/index.php?id=264 (accessed on 18 December 2019). [CrossRef]

19. Kpenavoun Chogou, S.; Lebailly, P.; Adegbidi, A.; Gandonou, E. Impact of Public Market Information System (PMIS) on Farmers Food Marketing Decisions: Case of Benin; European Association of Agricultural Economists (EAAE): Canterbury, UK, 2009.

20. Honfoga, G.; Kaki, S.; Adegbidi, A.; Kemonou Davo, A.A. Impact of the business services for farmers' organizations (ESOP) contract farming model on paddy producers' well-being in Dangbo District of Benin. Afr. J. Mark. Manag. 2016, 8, 32-43.

21. Mishra, A.K.; Kumar, A.; Joshi, P.K.; D'Souza, A. Impact of contract farming on yield, costs and profitability in low-value crop: Evidence from a low-income country. Aust. J. Agric. Resour. Econ. 2018, 62, 589-607. [CrossRef]

22. Miyata, S.; Minot, N.; Hu, D. Impact of Contract Farming on Income: Linking Small Farmers, Packers, and Supermarkets in China. World Dev. 2008, 37, 1781-1790. [CrossRef]

23. Yamane, T. Problems to Accompany Statistics, an Introductory Analysis, 2nd ed.; Harper \& Row: New York, NY, USA, 1967.

24. Becerril, J.; Abdulai, A. The impact of improved maize varieties on poverty in Mexico: A propensity score-matching approach. World Dev. 2010, 38, 1024-1035. [CrossRef]

25. Ali, A.; Abdulai, A. The adoption of genetically modified cotton and poverty reduction in Pakistan. J. Agric. Econ. 2010, 61, 175-192. [CrossRef]

26. Crost, B.; Shankar, B.; Bennett, R.; Morse, S. Bias from farmer self-selection in genetically modified crop productivity estimates: Evidence from Indian data. J. Agric. Econ. 2007, 58, 24-36. [CrossRef]

27. Faltermeier, L.; Abdulai, A. The impact of water conservation and intensification technologies: Empirical evidence for rice farmers in Ghana. Agric. Econ. 2009, 40, 365-379. [CrossRef]

28. Dibba, L.; Zeller, M.; Diagne, A. The impact of new Rice for Africa (NERICA) adoption on household food security and health in the Gambia. Food Secur. 2017, 9, 929-944. [CrossRef]

29. Mason, N.M.; Jayne, T.S.; Mofya-Mukuka, R. Zambia's input subsidy programs. Agric. Econ. (United Kingdom) 2013, 44, 613-628. [CrossRef]

30. Smale, M.; Mason, N. Hybrid Seed and the Economic Well-Being of Smallholder Maize Farmers in Zambia. J. Dev. Stud. 2014, 50, 680-695. [CrossRef]

31. Arouna, A.; Olounlade, A.O.; Diagne, A.; Biaou, G. Impact Assessment of Contract Farming on Rice Producers' Income: Benin Case Study. Ann. Sci. Agron. 2015, 19, 617-629, ISSN 1659-5009.

32. Kousar, R.; Makhdum, M.S.A.; Abbas, A.; Nasir, J.; Naseer, M.A.u.R. Issues and Impacts of the Apricot Value Chain on the Upland Farmers in the Himalayan Range of Pakistan. Sustainability 2019, 11, 4482. [CrossRef]

33. Heckman, J.J. Building bridges between structural and program evaluation approaches to evaluating policy. J. Econ. Lit. 2010, 48, 356-398. [CrossRef] [PubMed]

34. Wooldridge, J.M. Econometric Analysis of Cross Section and Panel Data; MIT Press: Cambridge, MA, US, 2010; ISBN 9780262294355.

35. Rubin, D.B. Estimating causal effects of treatments in randomized and nonrandomized studies. J. Educ. Psychol. 1974, 66, 688-701. [CrossRef] 
36. Diagne, A.; Demont, M. Taking a New Look at Empirical Models of Adoption: Average Treatment Effect Estimation of Adoption Rates and their Determinants. In Proceedings of the 2006 Annual Meeting, Queensland, Australia, 12-18 August 2006.

37. Rosenbaum, P.R. Observational Studies. In Springer Series in Statistics; Springer: New York, NY, USA, 2002; pp. 1-17.

38. Lee, M.-J. Micro-Econometrics for Policy, Program and Treatment Effects; Oxford University Press: London, UK, 2006; ISBN 9780191603044.

39. Imbens, G.W.; Angrist, J.D. Identification and Estimation of Local Average Treatment Effects. Econometrica 1994, 62, 467. [CrossRef]

40. Abadie, A. Semiparametric instrumental variable estimation of treatment response models. J. Econom. 2003, 113, 231-263. [CrossRef]

41. WFP. Monitoring Food Security; World Food Programme: Rome, Italy, 2012.

42. Bravo-Ureta, B.E.; Greene, W.; Solís, D. Technical efficiency analysis correcting for biases from observed and unobserved variables: An application to a natural resource management project. Empir. Econ. 2012, 43, 55-72. [CrossRef]

43. Wainaina, P.W.; Okello, J.J.; Nzuma, J.M. Impact of Contract Farming on Smallholder Poultry Farmers' Income in Kenya; International Association of Agricultural Economists (IAAE): Iguaçu, Brazil, 2012.

44. Sachiko, M. Impact of Contract Farming on Income; International Food Policy Research Institute: Washington, DC, USA, 2007.

45. Soullier, G.; Moustier, P. Impacts of contract farming in domestic grain chains on farmer income and food insecurity. Contrasted evidence from Senegal. Food Policy 2018, 79, 179-198. [CrossRef]

46. Glover, D.; Kusterer, K. Small Farmers, Big Business. Contract Farming and Rural Development. In Small Farmers, Big Business; Palgrave Macmillan UK: London, 1990; pp. 1-20.

47. Douroux, L. La position des agriculteurs en face de l'économie contractuelle. Économie rurale 1964, 60, 75-77. [CrossRef]

48. Ntakyo, P.R.; van den Berg, M. Effect of market production on rural household food consumption: Evidence from Uganda. Food Secur. 2019, 11, 1051-1070. [CrossRef]

49. Aringo, K.O. Impact of Contracted Sugarcane Farming on Household Food Security in Uriri Division-Kenya. A Research Paper Submitted in Partial fulfillment for The Award of Masters of Arts in Sociology (Rural Sociology \&Community Development Option) University of Nairobi Faculty of Arts Sociology Department. Nairobi, Kenya, October 2008. Available online: https://pdfs.semanticscholar.org/4cba/ eafbfc66f3a63e8fdcc68e757c01672152c9.pdf (accessed on 18 December 2019).

50. United-Nations. Provisional Guidelines on Standard International Age Classifications; United Nations: New York, NY, USA, 1982.

51. Guo, G.; Wen, Q.; Zhu, J. The Impact of Aging Agricultural Labor Population on Farmland Output: From the Perspective of Farmer Preferences. Math. Probl. Eng. 2015, 2015, 730648. [CrossRef]

52. Dzramedo, B.; Dabuo, R. Challenges and Sustainability of Smock Weaving within the West Gonja District of the Northern Region. Ghana J. Sci. Technol. Dev. 2015, 3, 36-43.

53. Just, R.E.; Zilberman, D. Stochastic structure, farm size and technology adoption in developing agriculture. Oxf. Econ. Pap. 1983, 35, 307-328. [CrossRef]

(C) 2020 by the authors. Licensee MDPI, Basel, Switzerland. This article is an open access article distributed under the terms and conditions of the Creative Commons Attribution (CC BY) license (http://creativecommons.org/licenses/by/4.0/). 